\title{
The Hadean-Archaean Environment
}

\author{
Norman H. Sleep \\ Department of Geophysics, Stanford University, Stanford, California 94305 \\ Correspondence: norm@stanford.edu
}

A sparse geological record combined with physics and molecular phylogeny constrains the environmental conditions on the early Earth. The Earth began hot after the moon-forming impact and cooled to the point where liquid water was present in $\sim 10$ million years Subsequently, a few asteroid impacts may have briefly heated surface environments, leaving only thermophile survivors in kilometer-deep rocks. A warm $500 \mathrm{~K}, 100$ bar $\mathrm{CO}_{2}$ greenhouse persisted until subducted oceanic crust sequestered $\mathrm{CO}_{2}$ into the mantle. It is not known whether the Earth's surface lingered in a $\sim 70^{\circ} \mathrm{C}$ thermophile environment well into the Archaean or cooled to clement or freezing conditions in the Hadean. Recently discovered $~ 4.3$ Ga rocks near Hudson Bay may have formed during the warm greenhouse. Alkalic rocks in India indicate carbonate subduction by $4.26 \mathrm{Ga}$. The presence of $3.8 \mathrm{Ga}$ black shales in Greenland indicates that S-based photosynthesis had evolved in the oceans and likely Fe-based photosynthesis and efficient chemical weathering on land. Overall, mantle derived rocks, especially kimberlites and similar $\mathrm{CO}_{2}$-rich magmas, preserve evidence of subducted upper oceanic crust, ancient surface environments, and biosignatures of photosynthesis.

ife possibly originated and definitely evolved Lon the early Earth. Several other articles in this collection pose specific questions for the Earth scientist. Benner et al. (2010) discuss the origin of ribose in boron containing fluids in serpentinite. One would like to know when, where, and if this was a likely rock environment. Deamer and Weber (2010) discuss energy sources and Hazen (2010) discusses mineral surfaces. The mineralogical composition of likely rocks and its tendency to provide chemical equilibrium directly involve geology. Gaucher et al. (2010) use the molecular biology of extant life to infer conserved traits that involved on the early Earth. Zahnle et al. (2007) and Nisbet et al. (2007) review conditions on the early Earth. I focus on illustrative specific issues that relate to molecular phylogeny and/or to use of the geological record.

Earth scientists ask whether inferences from molecular phylogeny make geological and ecological sense. They also use the Earth's geological record to tie phylogenic events to the Earth's absolute time scale. The lack of ancient preserved rocks hinders all these efforts to the point of grasping at straws. One may use the pittance of ancient rock samples working back from younger better recorded times. A parallel

Editors: David Deamer and Jack W. Szostak

Additional Perspectives on The Origins of Life available at www.cshperspectives.org

Copyright (C) 2010 Cold Spring Harbor Laboratory Press; all rights reserved; doi: 10.1101/cshperspect.a002527

Cite this article as Cold Spring Harb Perspect Biol 2010;2:a002527 
N.H. Sleep

approach uses physics to infer conditions are the earliest Earth and then works forward. Overall, the geologist provides a shopping list of likely conditions to biologists and draws biological inferences from the Earth's meager record.

As a caveat, it is conceivable that terrestrial life did not originate on our planet. Panspermia from outside the solar system is highly unlikely and replaces well-posed questions with speculations about an unknowable world. Yet the transfer of life between terrestrial planets in our solar system seems feasible. In fact, the origin of terrestrial life on Mars (McCay 2010) and/or the asteroid Ceres are more testable hypotheses than its origin on the Earth. These inactive bodies preserve very ancient geological records. Logistics preclude immediate appraisal. This subject is mostly beyond the scope of this review.

Finally, some definition of the terms "Hadean" and "Archaean" is necessary. Defining Hadean as predating the oldest rock is awkward in that a Hadean rock can then never be found. For this review, Hadean includes the late heavy bombardment before $\sim 3.8 \mathrm{Ga}$. It follows convention of considering the oldest well-preserved sedimentary rocks in Isua Greenland at $\sim 3.8 \mathrm{Ga}$ as Archaean (e.g., Rosing and Frei 2004). The Archaean ends at $\sim 2.5 \mathrm{Ga}$. The advent of $\mathrm{O}_{2}$ in the atmosphere at $\sim 2.45 \mathrm{Ga}$ is a practical boundary involving recognizable global event in the sedimentary record.

\section{BACKGROUND}

Some definition of life is necessary to focus discussion. Here, a self-organized and reproducing consortium of complicated chemical compounds that includes catalysts that extract energy from the environment suffices. The complexity of terrestrial life has a high degree of order, using a limited number of organic compounds as building blocks. It resembles writing in an alphabet, much more than the scribbling of a three year old.

I limit the scope of the article to life as we find on Earth. Today we have chemoautotrophic life that extracts energy ultimately from rocks and from photolysis in the air and water, photosynthetic life, and heterotrophs that eat products of other life. This partition creates semantic problems in discussing the earliest Earth. For example, organisms similar to modern heterotrophs could have eaten carbon compounds brought in by meteorites by reacting them with ferric iron from rocks. This resource persists today but is extremely meager compared with the bountiful products of photosynthesis. This potential prebiotic and early biotic substrate is beyond the scope of this article mainly because my knowledge of the geological record offers little insight; see Ehrenfreud (2010) and Zahnle (2010).

It is unproductive to precisely define when autocatalysis became life. It is also unnecessary for the Earth. Nascent life competes with nonlife (Nowak and Ohtsuki 2008). There is selection both for efficient gathering of resources and for faithful reproduction. Once the fidelity of reproduction crosses a threshold, life wins. The population explosion colonizes all connected environments on a time scale of years to thousands of years. It is highly unlikely that the Earth's meager geological record preserves this event.

The Earth scientist thus asks whether the Earth was habitable at a given time and whether it was in fact inhabited. A minimum requirement for habitability is temperature. There is a real upper limit for mundane life; the current record is $122^{\circ} \mathrm{C}$ (Takai et al. 2008). Gradual gradients to higher temperatures at depth in the rocks and sharp gradients around hydrothermal events have highly existed throughout geological time and with them the opportunity for evolution of more extreme thermophiles. Life cannot function at temperatures where water is solid. However, life likely arose in or around rocks rather than photosynthetically at the surface (Gaucher et al. 2010). Liquid water existed in the deep oceans and rocks on the early Earth even if the surface froze over. The second requirement is energy. As discussed later, the Earth began hot. There have always been hydrothermal systems to provide chemical disequilibria.

A rock record is necessary to tell whether the Earth was in fact inhabited. It is unlikely that morphological fossils will be found in rocks 
older than $3.8 \mathrm{Ga}$. Neither will biomarkers, that is, molecular fossils than can be associated with specific groups of organisms. The earth scientist is thus left with "biosignatures," indications of life that can range from weak to strong. This situation implies a functional discussion of life forms. For example, metamorphosed black shales in Isua Greenland contain abundant reduced carbon and some pyrite (Rosing and Frei 2004). This association is a biosignature for anoxygenic photosynthesis that oxidized sulfide to sulfate and the heterotrophic reaction of sulfate and organic matter in the sediments to produce pyrite. It is not a priori evident that the ancient organisms are the ancestors of modern organisms that fill these niches.

The section begins with the earliest Earth and considers the aftermath of its formation and the effects of large asteroid impacts, using physics, as the relevant terrestrial rock record is sparse. It then reviews the advent of continents where a meager but relevant rock record exists.

\section{Approach to Clement Conditions on the Earliest Earth}

The current paradigm is that the current EarthMoon system formed when a Venus-sized ( $\sim 0.9$ Earth mass) "target" planet collided with a Mars-sized ( $\sim 0.1$ Earth mass) "projectile" planet. Zahnle et al. (2007) and Nisbet et al. (2007) reviewed its aftermath and the early Earth in general. This subsection concentrates on features than might be preserved in the rock record and aspects directly related to life.

The Moon condensed from vaporized ejecta from the mantle of the projectile. It is sterile because it lost its volatile components including water in this process, rather than because its surface is airless. The energy of the impact melted the mantle of the Earth and vaporized significant volumes of rock. The top of the vapor atmosphere (that is the photosphere) radiated its heat to space at an effective temperature of $\sim 2300 \mathrm{~K}$. The entire mass of the mantle needed to pass repeatedly through the photosphere to vent its heat to space. The end of the process after $\sim 1000$ years left an atmosphere of traditional volatiles, a few hundred bars of water and 100-200 bars of $\mathrm{CO}_{2}$.

Water clouds soon condensed at the top of the atmosphere limiting the escape of heat to the runaway greenhouse threshold. The heat flow from the Earth's interior was $\sim 140 \mathrm{~W} / \mathrm{m}^{2}$. The surface remained hot 1800-2000 K, partially molten with some solid scum. Tidal heating from the Moon prolonged the episode. In $\sim 20$ million years, the surface and mantle of the Earth were solid rock and the heat flow waned to $\sim 0.5 \mathrm{~W} / \mathrm{m}^{2}$, similar to 1 millionyear-old modern oceanic crust.

Considerable $\mathrm{CO}_{2} \sim 100$ bars likely remained in the atmosphere at this stage as this compound is nearly insoluble in magma at this pressure and carbonates are unstable at the temperatures of molten rock, here $\sim 1800$ $\mathrm{K}$. This amount of $\mathrm{CO}_{2}$ was insufficient to trigger a runaway greenhouse on the early Earth, but enough to maintain a surface temperature of $\sim 500 \mathrm{~K}$ above a liquid water ocean (Kasting and Ackerman 1986; Sleep et al. 2001). (As in a pressure cooker, liquid water is stable at the high pressures, here a dense $\mathrm{CO}_{2}$ atmosphere and hydrothermal systems on the modern seafloor. The steam saturation pressure at $500 \mathrm{~K}$ is 26.5 bars, compared to the pressure of $\sim 250$ bars for a uniform layer of water with the mass of the present oceans.)

Calcium and magnesium carbonates were stable at the surface in equilibrium with basaltic rocks. However, carbonate minerals were stable only in the uppermost relatively cool region $(\sim 500 \mathrm{~m})$ of the oceanic crust. The limited mass of $\mathrm{CaO}$ and $\mathrm{MgO}$ (each $\sim 10 \%$ by weight) could take up worldwide only $\sim 10$ bars of $\mathrm{CO}_{2}$ at any one time in carbonates. Repeated carbonatization of the oceanic crust and it subsequent subduction of some kind was necessary to sequester all the $\mathrm{CO}_{2}$ in the Earth's deep interior. This process became more efficient as the interior cooled. Continental weathering and continental formation of carbonate need not have been involved. Note that subduction implies island arcs in the tectonic sense, but not necessarily islands above sea level.

It is unclear how long a warm $500 \mathrm{~K} \mathrm{CO}_{2}$ greenhouse persisted. Zahnle et al. (2007) prefer 
N.H. Sleep

a range between the minimum time of $\sim 10$ million years to subduct the available $\mathrm{CO}_{2}$ to 100 million years Sleep et al. (2001) and Zahnle et al. (2007) with caveats could not identify any mechanism that would prolong a thermophile environment at $70-100^{\circ} \mathrm{C}$. Once the $\mathrm{CO}_{2}$ was subducted, a dynamic balance between rock sinks including weathering at the surface and reaction of $\mathrm{CO}_{2}$ with the oceanic crust to form carbonates maintained a modest concentration of $\mathrm{CO}_{2}$ in the air and the ocean. I return to this topic in the next subsection on asteroid impacts.

With regard to the implications of early life, mantle-derived igneous rocks (once the mantle became essentially solid) were similar to modern ones, that is, basalts and more Mg-rich and higher temperature komatiites. The precise composition of komatiite depends on its depth of origin and hence of the temperature in the upwelling mantle (Arndt 2003). It is also conceivable that a $\sim 150-\mathrm{km}$-thick "magma ocean" of basaltic mush analogous to the mush chamber at fast ridge axis (Fig. 1) capped the mantle at some times (Zahnle et al. 2007; Sleep 2007). Igneous activity and hydrothermal circulation have been present throughout Earth history. The Earth has always recycled buried volatiles including carbon and water back to the surface.

With regard to the composition of the ocean, the behavior of modern hydrothermal systems provides analogy (Sleep et al. 2001). The ancient ocean as a whole cooled over millions of years toward clemency, passing through the P-T conditions beneath modern ridge axes. In particular, $\mathrm{Na}$ is much more abundant than $\mathrm{Cl}$ on the Earth. A dense liquid $\mathrm{NaCl}$ brine formed by the time the temperature reached $500^{\circ} \mathrm{C}$ if not before.

Basalt likely buffered the $\mathrm{pH}$ and the water chemistry; thermodynamic calculations indicate that carbonates are stable phases in water that has reacted with basalt (Sleep et al. 2001). The $\mathrm{pH}$ like the modern ocean was near neutral by the time it became habitable. A komatiite or peridotite/serpentinite buffered ocean would be more alkaline like modern vents in serpentinite. There was never a $\mathrm{HCl}-\mathrm{H}_{2} \mathrm{SO}_{4}$ ocean nor a $\mathrm{NaHCO}_{3}-\mathrm{Na}_{2} \mathrm{CO}_{3}$ one, as they would have been strongly out of equilibrium with basalt and also with komatiite or peridotite/ seprentinite.

The precise amounts of $\mathrm{NaCl}$ and water in the ancient surface ocean, however, are not evident. Knauth (2005) points out the higher
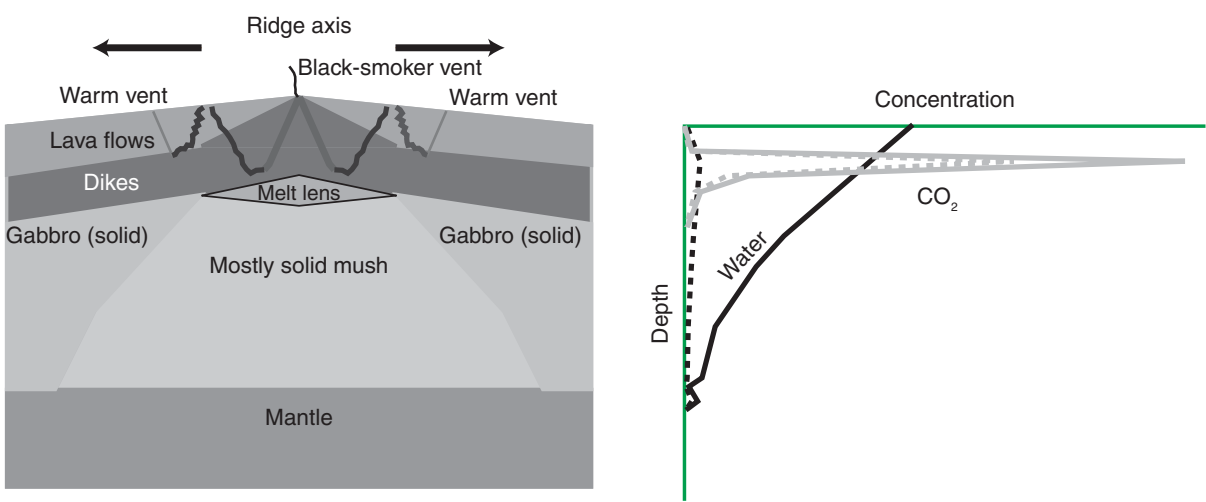

Figure 1. Schematic diagram shows cross section of ridge axis (left). Hot black smoker vents cool the magma lens and underlying mush chamber. Warm $20-60^{\circ} \mathrm{C}$ vents occur off axis. Carbonate minerals remove $\mathrm{CO}_{2}$ from seawater. $\mathrm{CO}_{2}$ is highly concentrated in a thin layer. The concentration before subduction (solid line) is somewhat greater than the concentration after subduction (dashed line). The concentration of water decreases slowly with depth (solid line). The subduction process removes most of the water into arc volcanics and returns it to the surface (dashed line). Mantle $\mathrm{CO}_{2}$ hence resides at high concentrations in rocks formed from the upper oceanic crust. These domains are the source for kimberlites and other $\mathrm{CO}_{2}$-rich magmas. Not to scale. 
salinity $1.5-2.0$ times present level is likely in the Hadean and Archaean because there was insufficient continental area to form closed seas where halite (rock salt, solid $\mathrm{NaCl}$ ) could accumulate by local evaporation of seawater. The direct geological record is not particularly helpful as halite is soluble in water and hence has a poor preservation potential compared with other rock types.

\section{Ground Zero on the Early Earth}

Zahnle et al. (2007) reviewed knowledge of the asteroid impacts on the early Earth. Little rock record exists, but the Moon provides a nearby well-preserved surface. Mars provides a most distant one. The impacting objects were mostly asteroids in solar orbit. It is straightforward to include the effect of the Earth's gravity in extrapolating its impact rate from the lunar one. Comets appear to have been a small fraction of the projectiles. The approach velocity of most comets is high enough compared to the escape velocities of the Moon and the Earth, that their gravity has little effect on the impact probability and impact energy.

The largest bodies are of interest here as they may sterilize an otherwise habitable planet. More interesting, they may have decimated life, leaving only predictable thermophile survivors. The killing mechanism of large projectiles is heat and the conservation of energy simplifies calculations. Basically an object larger that $\sim 300 \mathrm{~km}$ boils part of the ocean and leaves the rest of it uninhabitably hot. A $400-500 \mathrm{~km}$ diameter will boil the ocean. Thereafter water rains out (initially at $\sim 350^{\circ} \mathrm{C}$ ) of the atmosphere at $\sim 1 \mathrm{~m} / \mathrm{yr}$. The surface returns to clement conditions in a few thousand years.

A refuge exists in the surface below $\sim 1 \mathrm{~km}$ depth if the geothermal gradient is low enough that this "Goldilocks" region is cool enough to be habitable. Shallower regions are normally habitable but are sterilized. Deeper regions are too hot for life all the time. Some Goldilocks regions existed in oceanic crust by $4.37 \mathrm{Ga}$ in the thermal history calculation of Sleep (2007). As discussed in the next subsection, low-heat flow continental regions may have existed as early as $4.5 \mathrm{Ga}$.

The lunar record provides some calibration of the rate of large impacts on the Earth. It is obvious that the highland primordial crust still covers much of the lunar surface. That is, the Moon was hit by only a modest number of $>100 \mathrm{~km}$ diameter objects that would have exhumed deeper rocks. In comparison, the resurfacing rate of the Moon by large impacts between 4.5 and $3.8 \mathrm{Ga}$ was less than the rate that plate tectonics renew the oceanic crust over $\sim 100$ million years on the Earth.

Quantitatively, one object hits the Moon compared to $\sim 20$ hitting the much larger target Earth. That is, $\sim 14$ objects larger than the largest lunar impact are expected for the Earth. The largest lunar projectile was $\sim 200 \mathrm{~km}$ diameter. So a few objects greater than $\sim 300 \mathrm{~km}$ diameter are expected to have hit the Earth. Prediction is thus complicated by the statistics of small numbers. Zahnle and Sleep (2006) preferred zero to four impacts large enough to leave only thermophile survivors. Ryder (2002) preferred zero but acknowledged the possibility of a sterilizing event using essentially the same data, but a different scaling relationship between basin size and projectile size on the Moon.

The timing of the impacts is of interest. One view is that the projectiles were gradually used up as a tail to accretion. Zahnle et al. (2007) review that this hypothesis is currently not favored by orbital dynamicists, nor by what is know about absolute ages on the moon. Rather, changes in the orbits of Jupiter and Saturn perturbed asteroids out of previously stable orbits at $\sim 3.9 \mathrm{Ga}$. This hypothesis is obviously testable by renewed sampling of the Moon. It implies that the Earth's interior had cooled significantly by the time of serious impacts and the Goldilocks zones existed in its subsurface. Hopkins et al. (2008) infer the pressure and temperature of formation of zircon crystals of this age. They conclude that regions of modest heat flow and modest thermal gradient $\sim 30 \mathrm{~K} / \mathrm{km}$ existed then within continents.

Three additional environmental effects involve impacts. (1) Impacts of Fe-metal-bearing asteroids release $\mathrm{Fe}$ vapor into the air and 
N.H. Sleep

Fe-metal into the ocean and ejecta (Kasting 1990). The metal reacts with water to form ferrous oxide and hydrogen gas. Methane forms from these reactants and $\mathrm{CO}_{2}$. Ammonia forms from hydrogen and nitrogen gas. This may have led to transient reducing conditions in atmosphere, as in the experiments of Miller and Urey (1959). (2) Large impacts may exhume the mantle, providing serpentine at the surface and an environment where ribose may form as in Benner et al. (2010). In this vein, metamorphosed rock that was likely once serpentine (e.g., Friend et al. 2002) exists in the $3.8 \mathrm{Ga}$ Issua sequence in Greenland. Studies of other altered rocks indicate that circulating seawater contained significant boron (Chaussidon and Appel 1997). (3) Ejecta are highly reactive pulverized and partly glassy rocks. Basaltic, komatiitic, and mantle ejecta are potent $\mathrm{CO}_{2}$ sinks. They may have well drawn down atmospheric $\mathrm{CO}_{2}$ to the point that the Hadean oceans froze over (Sleep and Zahnle 2001).

\section{Zircons and the Earliest Continents}

Hadean and Archaean detrital zircons from the 3.3 Ga Jack Hills formation in Australia have been extensively studied (see Cavosie et al. 2007). The mere survival of these samples over time indicates that regions akin to continental crust existed by $4.4 \mathrm{Ga}$ and possibly as early as $4.5 \mathrm{Ga}$. For present purposes, zircon $\left(\mathrm{ZrSiO}_{4}\right)$ is very stable from weathering temperatures to low igneous temperatures $<700^{\circ} \mathrm{C}$. It contains $\mathrm{U}$, Th, Hf, and $\mathrm{Li}$ as trace components. It sequesters radiogenic lead that facilities absolute age determination. The chemical diffusion of its trace elements slow facilitating studies of its source rock.

Overall these zircons indicate that their granitic host rocks formed partly at the expense of clay-rich sediments, hence indicate the existence of subaerial land masses. Oxygen isotopic variations (Cavosie et al. 2005, 2006, 2007) and lithium abundance and isotopic variations (Ushikubo et al. 2008) are the best evidence. These data do not bear on whether weathering occurred in a $\mathrm{CO}_{2}$-rich atmosphere at $\sim 500 \mathrm{~K}$ or at clement conditions.
Ushikubo et al. (2008) prefer the former as an explanation for the scarcity of Hadean rocks. This group correctly states that high temperature and high $\mathrm{CO}_{2}$ facilitate chemical weathering. However, the exhumation of granitic rocks ceases once the surface has been beveled to sea level. Tectonics in addition of climate are thus necessary to recycle crustal hard rocks.

Continuing with tectonics, the Jack Hills zircons provide a potential constraint on the rate of tectonic activity. Cavosie et al. (2004) report that peaks and gaps exist in their zircon age suite. The gaps are $50-100$ million years compared with 500-1000 million years for modern suites. Zahnle et al. (2007) and Sleep (2007) made the straightforward assumption that the duration of the gaps indicates the typical rate of tectonics. That is, tectonic processes recycled oceanic and continental crust at $\sim 10$ times the present rate. With this reasoning, Hadean heat flow was approximately three times its present value or $\sim 0.2 \mathrm{~W} / \mathrm{m}^{2}$, compatible with their thermal modeling. Older lithosphere was $\sim 40 \mathrm{~km}$ thick, enough to behave like modern plates and to transport continents.

\section{RECENT RESULTS}

I focus on recent work that relates to recognition of specific environmental conditions or specific functional biology on the early Earth. The subfield is new because evidence comes partly from "hard" igneous and metamorphic rocks, rather than "soft" sedimentary and lowgrade metamorphic rocks. Hard rock petrologists have not been traditionally trained to seek biosignatures and paleontologists have traditionally focused on soft rocks.

\section{World's Oldest Rocks Locality near Hudson Bay}

O'Neil et al. (2009) described a locality of Hadean rocks near Hudson Bay. Their methodology used a short-lived radioactive isotopic system where isotope ${ }^{146} \mathrm{Sm}$ decayed to the stable isotope ${ }^{142} \mathrm{Nd}$ with a half-life of $\sim 103$ million years O'Neil et al. (2009) obtained an isochron age of $4.28 \mathrm{Ga}$ from their suite of 
samples. At a minimum, their data point to the early formation and persistence of crust. The Hudson Bay suite has ${ }^{142} \mathrm{Nd} /{ }^{144} \mathrm{Nd}$ that is less than the bulk mantle value; the daughter element $\mathrm{Nd}$ preferentially enters mantle derived melts and continental crust relative to Sm. Significant changes in the daughter/stable isotope ratio ${ }^{142} \mathrm{Nd} /{ }^{144} \mathrm{Nd}$ could have occurred only within a few half-lives after the Earth's formation and the rocks must have remained as a chemically isolated domain since then.

It is unclear whether $\sim 4.3 \mathrm{Ga}$ is actually the eruption age, rather than the age of the source region of the melt. If eruption occurred at $\sim 4.3 \mathrm{Ga}$, the rocks provide the first direct evidence of the Hadean surface environment. Chemically these "faux amphibolites" appear to be metamorphosed basaltic rocks, possibly pyroclastic flows. They are greatly depleted in calcium relative to the composition of pristine basalts, but otherwise resemble mantle-derived igneous rocks. Such depletion does not occur in modern weathering.

Two candidate Hadean environments that might selectively deplete $\mathrm{Ca}$ are obvious from the previous section: (1) Hot $200^{\circ} \mathrm{C}$ rain falls during the warm $\mathrm{CO}_{2}$ greenhouse, indicating an uninhabitable abiotic environment until at least $\sim 4.3 \mathrm{Ga}$. (2) Hot $350^{\circ} \mathrm{C}$ low $\mathrm{CO}_{2}$ rain falls in the few 1000 year aftermath of an ocean boiling impact. Geochemical studies as to what alteration occurs in these environments are not available. Note that precipitation-fed freshwater hydrothermal systems exist in Iceland. Some of these systems are likely to have the temperature, pressure, and $\mathrm{CO}_{2}$ concentrations discussed earlier and thereby provide some analogy.

\section{Advent of Photosynthesis}

I take the availability of essentially modern sunlight as a given in discussing the advent of photosynthesis. The Sun had approached the main sequence (hydrogen burning to helium) and was $\sim 70 \%$ as bright as present by the time the Earth had cooled to habitable conditions (e.g., Zahnle et al. 2007). Dust from impacts and volcanoes transiently clouded the sky, but there is no evident mechanism that would keep light from usually reaching the surface. Environments where any viable photosynthetic organisms were able to endure transient darkness certainly existed, including polar regions and lakes and land prone to burial by snow, mud, and dust. Modern sulfur-based photosynthetic microbes (see the following discussion) are able to act facultatively as heterotrophs and survive transient darkness. (Canfield and Raiswell 1999; Nisbet and Fowler 1996; Xiong et al. 2000).

Still the first terrestrial life forms were probably chemoautotrophic rather than photoautotrophic (Gaucher et al. 2010). It is unclear whether the first cellular life form lived at high or low temperatures. The Earth's climate may have lingered at a thermophile, but habitable condition $\sim 70^{\circ} \mathrm{C}$, well into the Archaean. The geological record is not definitive at present (e.g., Zahnle et al. 2007). The weathering rate would obviously be higher at high $\mathrm{CO}_{2}$ atmospheric concentrations and high surface temperatures. The Archaean rock record, however, has been used to support both modern (Holland 1984; Condie et al. 2001; Sleep and Hessler 2006) and rapid rates (Schwartzman 2002). The straightforward interpretation of oxygen (e.g., Knauth and Lowe 2003) and silicon (Robert and Chaussidon 2006) isotopic ratios in ancient marine cherts indicates high temperatures.

Gaucher et al. (2008, 2010) query molecular phylogeny in this regard. The last universal common ancestor (LUCA) is often but not universally regarded to be thermophile. The maximum temperature of stability of reconstructed nodal proteins (from the last common ancestors of major clades in the tree of life) systematically increases from young to old nodes.

The discussion of the early Earth in this article introduces three well-known endmember possibilities with these results. (1) The Hadean climate after the early warm greenhouse ceased was clement or icy. Life originated and colonized the planet, some species adapting to thermophile lifestyles at hydrothermal events and in the kilometer-deep surface. A large asteroid impact boiled much of the ocean leaving only thermophile survivors. The descendants of the survivors adaptively radiated colonize 
N.H. Sleep

low-temperature environments. High-temperature proteins were lost over time in the lowtemperature branches. (2) The same phylogeny occurred except that the thermophile organisms outcompeted their low-temperature relatives, leaving an apparent LUCA bottleneck without a sudden mass extinction (Miller and Lazcano 1995). (3) The climate cooled slowly after the end of the $\mathrm{CO}_{2}$ greenhouse and only thermophile organisms existed at the end of the Hadean and the temperature was still $50-70^{\circ} \mathrm{C}$ at $\sim 3.3 \mathrm{Ga}$ (Gaucher et al. 2008, 2010).

The first two possibilities have similar molecular genetic implications and geological implications until one finds evidence of a Hadean massive impact. Mat et al. (2008) call such phylogenies "hot cross." The accessible Archaean geological record bears on third possibility, and by potential elimination the other two.

It is relevant to attempt to tie phylogeny to absolute geological time. Sleep and Bird (2007, 2008) noted a difference between ecologies based on photosynthesis with those based on chemoautotrophy that this allows correlation in a functional sense. Briefly, a chemoautotrophic niche depends on a flux of chemical disequilibrium from rocks in the earth or photolysis in the air or water. For example, consider methanogenesis

$$
\mathrm{CO}_{2}+4 \mathrm{H}_{2} \Rightarrow \mathrm{CH}_{4}+2 \mathrm{H}_{2} \mathrm{O}
$$

The flux of $\mathrm{H}_{2}$ mainly from serpentinite limits the productivity of this niche. Acetogenesis is a related niche

$$
2 \mathrm{CO}_{2}+4 \mathrm{H}_{2} \Rightarrow 2 \mathrm{CH}_{2} \mathrm{O}+2 \mathrm{H}_{2} \mathrm{O}
$$

which provides complex organic matter (idealized formula $\mathrm{CH}_{2} \mathrm{O}$ ) for the cell as well as energy if the reactants $\mathrm{CO}_{2}$ and $\mathrm{H}_{2}$ are abundant (e.g., Hoehler et al. 1998). As the forward reactions provide energy, there are no heterotrophic niches for the back reaction.

Overall, such niches are dependable, but involve very modest primary productivities. Organic carbon forms in small amounts and there is little tendency for it to accumulate in shale, a weathered product that is already near chemical equilibrium with its environment. The microbes have little available energy to accelerate weathering of the rocks. Hence, recognition of pre-photosynthetic biology in the rock record is quite difficult.

In contrast, photosynthesis has produced an obvious ubiquitous rock record on the Earth. For example, the crust of the Earth is grossly modified by photosynthesis. It is far more oxidized than mantle-derived igneous rocks (Lecuyer and Ricard 1999). The excess oxygen exceeds that to balance buried reservoirs of organic carbon (see Sleep and Bird 2008). It is likely that biological methane from photosynthesis allowed $\mathrm{H}_{2}$ to escape to space before the oxidation of the Earth's atmosphere at $\sim 2.45 \mathrm{Ga}$ (Catling et al. 2001), leaving the oxygen from water behind. Subduction of organic carbon-rich sediments into the mantle is less likely but possible. These processes need not have involved oxygenic photosynthesis.

Photosynthesis may have evolved from hydrogen-based photocatalysis with the net effect of reaction (2). Sulfur and iron have multiple oxygen states suitable for photosynthetic ecology with heterotrophy. The idealized reactions are

$$
\begin{gathered}
2 \mathrm{CO}_{2}+\mathrm{S}^{-2}+2 \mathrm{H}_{2} \mathrm{O}+h \nu \\
\Rightarrow 2 \mathrm{CH}_{2} \mathrm{O}+\mathrm{SO}_{4}^{-2}
\end{gathered}
$$

(e.g., Grassineau et al. 2001) and

$$
\begin{gathered}
\mathrm{CO}_{2}+4 \mathrm{FeO}+\mathrm{H}_{2} \mathrm{O}+h v \\
\Rightarrow \mathrm{CH}_{2} \mathrm{O}+2 \mathrm{Fe}_{2} \mathrm{O}_{3}
\end{gathered}
$$

(e.g., Ehrenrich and Widdel 1994; Kappler and Newman 2004). Modern heterotrophic microbes obtain usable energy from the back reaction (3) with sulphate (Nisbet and Fowler 1996; Canfield and Raiswell 1999; Xiong et al. 2000), and back reaction (4) with ferric iron (Schröder et al. 2003; Luu and Ramsey 2003).

The presence of heterotrophy causes each $\mathrm{C}$ atom liberated by erosion, metamorphism, or volcanism to cycle many times between organic 
carbon and $\mathrm{CO}_{2}$ before it is buried again. The organic carbon thus accumulates in preferred environments like black shale where quick burial sequesters it from oxidants. Metamorphosed black shale occurs in $\sim 3.8 \mathrm{Ga}$ rocks in Isua Greenland with pyrite (Rosing and Frei 2004). This indicates that S-based photosynthesis and heterotrophy existed by that time.

As with the origin of life itself (Nowak and Ohtsuki 2008), an unstable threshold exists. The nascent anoxygenic photosynthetic microbes likely used hydrogen as their main substrate (reaction 2). They facultatively used $\mathrm{FeO}$ and/or sulfide to increase their productivity. There was thus selection toward using less scarce $\mathrm{H}_{2}$ in the mix. The first microbe that could dispense altogether with $\mathrm{H}_{2}$ proliferated with its productivity increasing by a factor of thousands above the previous total primary productivity of the Earth. It occupied all suitable environments on the scale of years to thousand of years. Its descendents held most of the tickets in the subsequent evolutionary lottery.

Available molecular phylogeny is compatible with this inference. Bacterial photosynthesis evolved just once. Photosystems I and II are related (e.g., Sadakar et al. 2006; Barber 2008). Battistuzzi et al. (2004) and Battistuzzi and Hedges (2009) proposed that most bacteria clades descend from the original photosynthetic ancestor. Sleep and Bird (2008) called the clade descending from the original photosynthesizer with the obvious informal name Photobacteria. Battistuzzi et al. (2004) and Battistuzzi and Hedges (2009) further divided Photobacteria into Hydrobacteria that remained in the ocean and Terrabacteria that colonized land.

With regard to the rock record, Sleep and Bird (2008) noted that the photosynthetic Terrabacteria colonists faced a dearth of $\mathrm{FeO}$ and sulfide on land. Sulfur $(0.1 \%$ in basalt [e.g., and Bird 1995]) is much less common than FeO ( $\sim 10 \%$ in basalt [e.g., Krauskopf and Bird 1995]) in most common rocks. Note that casual observations of volcanoes over estimate the abundance of sulfur. Elemental sulfur "brimstone" is obviously common at volcanic vents. Physically, sulfur species $\left(\mathrm{H}_{2} \mathrm{~S}, \mathrm{~S}_{8}\right.$, and $\mathrm{SO}_{2}$ ) exsolve from magma at low pressures.
The $\mathrm{FeO}$ component of the magma stays in the solid. Local sulfur-rich oases existed on land; I do not intend to contend that S-rich land volcanic vents should be excluded as potential prebiotic and early biotic environments.

Returning to land away from volcanoes, sulfate from reaction (3) is quickly leached from soils. Moreover, the FeO was locked up in minerals and volcanic glass. There was selection for soil organisms that could efficiently weather Fe-rich rocks. Notably Terrabacteria include Actinobacteria that live in soil and photosynthetic Cyanobacteria. Blank and SánchezBaracaldo (2010) traces the molecular phylogeny of cyanobacteria to fresh water organisms. Extraction of $\mathrm{FeO}$ from rocks by an anoxygenic photosynthetic community may well produce distinctive geochemical signals.

Returning the protein phylogeny (Gaucher et al. 2008, 2010), the occurrence of 3.8 Ga black shale (Rosing and Frei 2004) ties their nodes to geological time. The implications do not depend on the precise phylogenic tree of Battistuzzi et al. (2004) and Battistuzzi and Hedges (2009), only that efficient photosynthesis and the colonization of land predate $3.8 \mathrm{Ga}$. If this is correct, it is reasonable that the hightemperature proteins at the nodes of Gaucher et al. (2008) occurred in the Hadean following a high temperature bottleneck from an asteroid impact.

\section{Paleontology of the Earth's Mantle}

Subduction has recently been found to sequester material from early in the Earth's history. The occurrence of diamonds ultimately derived from subducted organic carbon in kimberlites (used loosely throughout this article) has been known from some time (Nisbet et al. 1994). The subsection reviews other examples that can be tied to environmental and biological processes.

Kimberlites form by partial melting of carbonate-rich domains in the Earth's mantle (Fig. 1). They react extensively with the Earth's lithosphere on the way up (Francis and Patterson 2009). Still, they retain isotope and trace element signatures of their pre-subduction 
N.H. Sleep

history and pre-eruption source region. The carbonate-rich sources of kimberlites come significantly from subducted oceanic crust that reacted with warm $20-60^{\circ} \mathrm{C}$ circulating seawater near ridge axes. As already noted, this process is the major mantle sink of $\mathrm{CO}_{2}$; all the Earth's $\mathrm{CO}_{2}$ was sequestered in this way at the end of the warm $\mathrm{CO}_{2}$ greenhouse. The process involves chemical reaction with the surface environment and the shallow (less than $1 \mathrm{~km}$ ) oceanic crust started subduction near sediments.

Upadhyayet al. (2009) reported low values of ${ }^{142} \mathrm{Nd} /{ }^{144} \mathrm{Nd}$ in a $1.48 \mathrm{Ga}$ alkalic complex in India intruded into 3.6 Ga crust in India. These rocks contain calcite as a trace phase and other trace elements indicating that a small fraction of partial melting occurred in a $\mathrm{CO}_{2}$-rich source region. They authors preferred a sequence of events where the anomalous $\mathrm{Nd}$ domain formed in the Hadean, rocks derived from it were emplaced in the deep lithosphere at $\sim 3.6 \mathrm{Ga}$ and then remobilized at $1.48 \mathrm{Ga}$. In general, kimberlites liberated from the mantle often freeze in the lithosphere and form secondary melts when reheated or assimilated by subsequent magma (Tappe et al. 2008). With regard to habitability, these data indicate the subduction of carbonatized oceanic crust at $\sim 4.26 \mathrm{Ga}$.

Data on kimberlites indicate that these rocks in fact come from subducted carbonates and retain a strong biosignature. For example, Zartman and Richardson (2005) found that that $\mathrm{U} / \mathrm{Th}$ doubled from its bulk Earth value from $2.7 \mathrm{Ga}$ to the recent. Chemically, U and Th behave as immobile elements during anoxic weathering. However, $\mathrm{U}$ is oxidized to the soluble oxidation state +6 if oxygen is present and is carried by rivers into the ocean and eventually into the oceanic crust, increasing the $\mathrm{U} / \mathrm{Th}$ ratio above the bulk Earth value.

Thallium isotopes are another mantle biosignature that can be associated with a specific biological process and subduction. Circulating oxic seawater leaches thallium from the shallow oceanic crust (layer 2A). This thallium accumulates in manganese nodules on the seafloor, and the process fractionates thallium isotopes between the two reservoirs (Nielsen et al. 2006a). Nielsen et al. (2006b) detected thallium isotope variations with the expected coupled chemical variations in recent Hawaiian basalts. The deep ocean became suboxic at $\sim 1.8 \mathrm{Ga}$ (Slack et al. 2007, 2009).

\section{CHALLENGES AND FUTURE RESEARCH DIRECTIONS}

There is enough information from physics and the rock record to provide biologists with candidate environmental conditions on the early Earth. The Earth began at rock-vapor temperatures and gradually cooled to habitability over 20-120 million years By the time it was habitable, its mantle was mostly solid, but a few $100 \mathrm{~K}$ hotter than present. Volcanic rocks erupted to the surface and hydrothermal water circulated through hot rocks. At least some continental mass was exposed above sea level. The modern Earth provides a qualitative analog with basalts, continental granites, and weathering. I did not attempt to deduce the relatively and absolute land areas of various rock types, as applicable data on ancient sediments is not available. Geochemists are able to predict differences in composition between Hadean and modern, for example, with hot mantle-derived komatiitic rocks (Arndt 2003).

River run-off and reaction with seafloor basalt and seafloor sediment dynamically buffer the chemistry of seawater. Overall, evaporation does not affect ocean chemistry on the sense that the water eventually returns in rain and run-off. Continents with local evaporation provide a much wider repertoire of fluid and rock chemistries. Lakes may be essentially fresh water. Other lakes in closed basins accumulate alkalis as inflow continually evaporates. Lakes near volcanoes may become acid. Such environments are far from equilibrium from basalt. These types of Darwin's warm pond are potential venues for the origin of life.

Asteroid impacts punctuated an otherwise habitable environment. Until direct record is found, the number of impacts that left only thermophile survivors is unknown because of the statistics of small numbers. Renewed lunar exploration, however, will give much better constraints on the flux and timing of these objects. 
Finally, photosynthesis appeared before the good rock record at $3.8 \mathrm{Ga}$. Its effects are pervasive in both the crust and mantle. A biological process in one place thus may have profound effects elsewhere. Work on recognizing biosignatures in mantle derived igneous rocks is just beginning. Kimberlites that sequester subducted carbonate in the oceanic crust (Fig. 1) are especially promising.

\section{REFERENCES}

Arndt N. 2003. Komatiites, kimberlites, and boninites. J Geophys Res 108: 2293. doi: 10.1029/2002JB002157.

Barber J. 2008. Photosynthetic generation of oxygen. Phil Trans R Soc B363: 2665-2674.

Battistuzzi FU, Hedges SB. 2009. A major clade of prokaryotes with ancient adaptations to life on land. Mol Biol Evol 26: 335-343.

Battistuzzi FU, Feijao A, Hedges SB. 2004 A genomic timescale of prokaryote evolution: Insights into the origin of methanogenesis, phototrophy, and the colonization of land. Evolutionary Biol 4: 44. doi: 10.1186/ 1471-2148-4-44.

Benner SA, Kim H.-Y, Kim M.-J, Ricardo A. 2010. Planetary organic chemistry and the origins of biomolecules. Cold Spring Harb Perspect Biol 2: a003467.

Blank CE, Sánchez-Baracaldo P. 2010. Timing of morphological and ecological innovations in the cyanobacteriaA key to understanding the rise in atmospheric oxygen. Geobiology 10: (in press).

Canfield DE, Raiswell R. 1999. The evolution of the sulfur cycle. Am J Sci 299: 697-723.

Catling DC, Zahnle KJ, McKay CP. 2001. Biogenic methane, hydrogen escape, and the irreversible oxidation of early Earth. Science 293: 839-843.

Cavosie AJ, Valley JW, Wilde SA. 2007. The oldest terrestrial mineral record: A review of 4400 to $3900 \mathrm{Ma}$ detrital zircons from Jack Hills, Western Australia. In Earth's oldest rocks, developments in precambrian geology (ed. Van Kranendonk M.J., Smithies R.H., Bennett V.), pp. 91-111. Elsevier, Amsterdam.

Cavosie AJ, Valley JW, Wilde SA, E.I.M.F. 2005. Magmatic $\delta^{18} \mathrm{O}$ in $4400-3900 \mathrm{Ma}$ detrital zircons: A record of the alteration and recycling of crust in the Early Archean. Earth Planet Sci Lett 235: 663-681.

Cavosie AJ, Valley JW, Wilde SA, E.I.M.F. 2006. Correlated microanalysis of zircon: Trace element, $\delta 18 \mathrm{O}$, and $\mathrm{U}_{-}$ $\mathrm{Th}-\mathrm{Pb}$ isotopic constraints on the igneous origin of complex N3900 Ma detrital grains. Geochim Cosmochim Acta 70: 5601-5616.

Cavosie AJ, Wilde SA, Liu D, Weiblen PW, Valley JW. 2004. Internal zoning and $\mathrm{U}-\mathrm{Th}-\mathrm{Pb}$ chemistry of Jack Hills detrital zircons: A mineral record of early Archean to Mesoproterozoic (4348-1576 Ma) magmatism. Precambrian Res 135: 251-279.

Chaussidon M, Appel PWU. 1997. Boron isotopic composition of tourmalines from the 3.8-Ga-old Isua supracrustals, West Greenland: Implications on the delta B-11 value of early Archean seawater. Chem Geol 136: $171-180$.

Condie KC, DesMarais DJ, Abbott D. 2001. Precambrian superplumes and supercontinents: A record in black shales, carbon isotopes, and paleoclimates? Precambrian Res 106: 239-260.

Deamer D, Weber A. 2010. The cell. Cold Spring Harb Perspect Biol 2: a004929.

Ehrenfreund P. 2010. Intersteller organics \& delivery. Cold Spring Harb Perspect Biol 2: a002097.

Ehrenreich A, Widdel F. 1994 Anaerobic oxidation of ferrous iron by purple bacteria, a new type of phototrophic metabolism. Appl Environ Microbiol 60: 4517-4526.

Francis D, Patterson M. 2009. Kimberlites and aillikites as probes of the continental lithospheric mantle. Lithos 109: $72-80$.

Friend CRL, Bennett VC, Nutman AP. 2002. Abyssal peridotites $>3,800 \mathrm{Ma}$ from southern West Greenland: Field relationships, petrography, geochronology, whole-rock and mineral chemistry of dunite and harzburgite inclusions in the Itsaq Gneiss Complex. Contrib Mineral Petrol 143: 71-92.

Gaucher EA, Govindarajan S, Omjoy K, Ganesh OK. 2008. Palaeotemperature trend for Precambrian life inferred from resurrected proteins. Nature 451: 704-708.

Gaucher EA, Kratzer JT, Randall RN. 2010. Deep phylogenyhow a tree can help characterize early life on earth. Cold Spring Harb Perspect Biol 2: a002238.

Grassineau NV, Nisbet EG, Bickle MJ, Fowler CMR, Lowry D, Mattey DP, Abell P, Martin A. 2001. Antiquity of the biological sulphur cycle: Evidence from sulphur and carbon isotopes in 2700 million-year-old rocks of the Belingwe Belt, Zimbabwe, Proc Roy Soc Biol Sci Series B 268: $113-119$.

Hazen W. 2010. Mineral surfaces, geochemical complexities, and the origins of life. Cold Spring Harb Perspect Biol 2: a002162.

Hoehler TM, Alperin MJ, Albert DB, Martens CS. 1998. Thermodynamic control on $\mathrm{H}_{2}$ concentrations in an anoxic marine sediment. Geochimica Cosmochimica Acta 62: 1745-1756.

Holland HD. 1984. The chemical evolution of the atmosphere and oceans. Princeton University Press, Princeton.

Hopkins M, Harrsion MT, Manning CE. 2008. Low heat flow inferred from $>4 \mathrm{Gyr}$ zircons suggests Hadean plate boundary interactions. Nature 456: 493-496.

Kappler A, Newman DK. 2004 Formation of Fe(III) minerals by $\mathrm{Fe}(\mathrm{II})$-oxidizing photoautotrophic bacteria. Geochim Cosmochim Acta 68: 1217-1226.

Kasting JF. 1990. Bolide impacts and the oxidation-state of carbon in the Earth's early atmosphere. Origins Life Evolution Biosphere 20: 199-231.

Kasting JF, Ackerman TP. 1986. Climatic consequences of very high-carbon dioxide levels in the Earth's early atmosphere. Science 234: 1383-1385.

Knauth LP. 2005. Temperature and salinity history of the Precambrian ocean: Implications for the course of microbial evolution. Palaeogeo Palaeoclimatol Palaeoecol 219: $53-69$. 
N.H. Sleep

Knauth LP, Lowe DR. 2003. High Archean climatic temperature inferred from oxygen isotope geochemistry of cherts in the 3.5 Ga Swaziland Supergroup, South Africa. Geo Soc Am Bull 115: 566-580.

Krauskopf KB, Bird DK. 1995. Introductiion to geochemistry. 3rd edn. p. 647, McGraw-Hill, New York, NY.

Lecuyer C, Ricard Y. 1999. Long-term fluxes and budget of ferric iron: Implication for the redox states of the Earth's mantle and atmosphere. Earth Planetary Sci Lett 165: 197-211.

Luu Y-S, Ramsey JA. 2003. Review: Microbial mechanisms of accessing insoluble $\mathrm{Fe}(\mathrm{III})$ as an energy source. World J Microbiol Biotechnol 19: 215-225.

Mat W-K, Xue H, Wong T-F. 2008. The genomics of LUCA. Frontiers Bioscience 13: 5605-5613.

McCay CP. 2010. An origin of life on Mars. Cold Spring Harb Perspect Biol 2: a003509.

Miller SL, Lazcano A. 1995. The origin of life-Did it occur at high temperatures, J Mol Evol 41: 689-692.

Miller SL, Urey HC. 1959. Organic compound synthesis on the primitive Earth. Science 130: 245-251.

Nielsen SG, Rehkamper M, Norman MD, Halliday AN, Harrison D. 2006b. Thallium isotopic evidence for ferromanganese sediments in the mantle source of Hawaiian basalts. Nature 439: 314-317.

Nielsen SG, Rehkamper M, Teagle DAH, Butterfield DA, Alt JC, Halliday AN. 2006a. Hydrothermal fluid fluxes calculated from the isotopic mass balance of thallium in the ocean crust. Earth Planet Sci Lett 251: $120-133$.

Nisbet EG, Fowler CMR. 1996. The hydrothermal imprint on life; did heat-shock proteins, metalloproteins and photosynthesis begin around hydrothermal vents? In Tectonic and biological segmentation of mid-ocean ridges (ed. MacLeod CJ, Tyler PA, Walker CL), pp. 239-251. Geological Society of London Special Publication.

Nisbet EG, Mattey DP, Lowry D. 1994. Can diamonds be dead bacteria? Nature 367: 694-694.

Nisbet E, Zahnle K, Gerasimov MV, Helbert J, Jaumann R, Hofmann BA, Benzerara K, Westall F. 2007. Creating habitable zones, at all scales, from planets to mud microhabitats, on Earth and on Mars. Space Sci Rev 129: 79-121.

Nowak MA, Ohtsuki H. 2008. Prevolutionary dynamics and the origin of evolution. Proc Natl Acad Sci 105: 14924-14927.

O’Neil J, Carlson RW, Francis D, Stevenson RK. 2009. Neodymium-142 evidence for Hadean mafic crust. Science 321: 1828-1831.

Robert F, Chaussidon M. 2006. A palaeotemperature curve for the Precambrian oceans based on silicon isotopes in cherts. Nature 443: 969-972.

Rosing MT, Frei R. 2004. U-rich Archaean sea-floor sediments from Greenland - indications of $>3700 \mathrm{Ma}$ oxygenic photosynthesis. Earth Planet Sci Lett 217: 237-244.

Ryder G. 2002. Mass flux in the ancient Earth-Moon system and benign implications for the origin of life on Earth. $J$ Geophys Res 107: 10.1029/2001JE001583

Sadekar S, Raymond J, Blankenship RE. 2006. Conservation of distantly related membrane proteins: Photosynthetic reaction centers share a common structural core. $\mathrm{Mol}$ Biol Evol 23: 2001-2007.

Schröder I, Johnson E, de Vries S. 2003. Microbial ferric iron reductases. FEMS Microbiology Reviews 27: 427-447.

Schwartzman D. 2002. Life, temperature, and the Earth, p. 272. Columbia University Press, NY.

Slack JF, Grenne T, Bekker A. 2009. Seafloor-hydrothermal $\mathrm{Si}-\mathrm{Fe}-\mathrm{Mn}$ exhalites in the Pecos greenstone belt, New Mexico, and the redox state of ca. 1720 Ma deep seawater. Geosphere 5: 302-314.

Slack JF, Grenne T, Bekker A, Rouxel OJ, Lindberg PA. 2007. Suboxic deep seawater in the late Paleoproterozoic: Evidence from hematitic chert and iron formation related to seafloor-hydrothermal sulfide deposits, central Arizona, USA. Earth Planetary Sci Lett 255: 243-256.

Sleep NH. 2007. Plate tectonics through time, Treatise on Geophysics Volume 9, (ed. Schubert G.), pp. 101-117. Oxford, Elsevier.

Sleep NH, Bird DK. 2007 Niches of the pre-photosynthetic biosphere and geologic preservation of Earth's earliest ecology. Geobiology 5: 101-117.

Sleep NH, Bird DK. 2008. Evolutionary ecology during the rise of dioxygen in the Earth's atmosphere. Philos Trans $R$ Soc B 363: 2651-2664.

Sleep NH, Hessler AM. 2006. Weathering of quartz as an Archean climatic indicator. Earth Planet Sci Lett 241: 594-602.

Sleep NH, Zahnle K. 2001. Carbon dioxide cycling and implications for climate on ancient Earth. J Geophys Res 106: $1373-1399$.

Sleep NH, Zahnle K, Neuhoff PS. 2001. Initiation of clement surface conditions on the early Earth. Proc Natl Acad Sci 98: $3666-3672$.

Takai K, Nakamura K, Toki T, Tsunogai U, Miyazki M, Miyazaki J, Hirayama H, Nakagawa S, Nunoura T, Horikoshi K. 2008. Cell proliferation at $122^{\circ} \mathrm{C}$ and isotopically heavy $\mathrm{CH}_{4}$ production by a hyperthermophilic methanogen under high-pressure cultivation. Proc Natl Acad Sci 105: 10949-10954.

Tappe S, Foley SF, Kjarsgaard BA, Romer RL, Heaman LM, Stracke A, Jenner GA. 2008. Between carbonatite and lamproite - Diamondiferous Torngat ultramafic lamprophyres formed by carbonate-fluxed melting of cratonic MARID-type metasomes. Geochim Cosmochim Acta 72: 3258-3286.

Upadhyay D, Scherer EE, Mezger K. 2009. ${ }^{142} \mathrm{Nd}$ evidence for an enriched Hadean reservoir in cratonic roots. Nature 459: 1118-1121.

Ushikubo T, Kita NT, Cavosie AJ, Simon A, Wilde SA, Rudnick RL, Valley JW. 2008. Lithium in Jack Hills zircons: Evidence for extensive weathering of Earth's earliest crust. Earth Planet Sci Lett 272: 666-676.

Xiong J, Fischer WM, Inoue K, Nakahara M, Bauer CE. 2000. Molecular evidence for the early evolution of photosynthesis. Science 289: 1724-1730.

Zahnle K. 2010. Atmospheric composition. Cold Spring Harb Perspect Biol 2: a004895.

Zahnle KJ, Sleep NH. 2006. Impacts and the early evolution of life. In Comets and the origin and evolution of life, 2nd 
ed. (ed. Thomas P.J., Hicks R.D., Chyba C.F., McKay C.P.), pp. 207-251. Springer, New York.

Zahnle K, Arndt N, Cockell C, Halliday A, Nisbet E, Selsis F, Sleep NH. 2007. Emergence of a Habitable Planet. Space Sci Rev 129: 35-78.

Zartman RE, Richardson SH. 2005. Evidence from kimberlitic zircon for a decreasing mantle $\mathrm{Th} / \mathrm{U}$ since the Archean. Chem Geol 220: 263-283.

\section{GLOSSARY}

Basalt: The black volcanic rock that erupts for example in Hawaii and Iceland. It forms by moderate $<25 \%$ partial melting of the earth's mantle. It is the most common volcanic rock on the Earth, the Moon and Mars.

Fast ridge axis: Originally, a ridge where the spreading rate is rapid enough that a central peak rather than a central valley exists at the axes. The morphology occurs when the full spreading rate is greater than $\sim 60 \mathrm{~km} /$ million years Fast ridges have steady state magma lens underlain by mush as shown in Figure 1.

Faux amphibolite: (transferred with partial translation from Québécois French): Rocks formed by the metamorphism of basalt containing the mineral amphibole. Ordinary amphibole in common amphibolite that formed from basalt is rich is calcium, idealized formula $\mathrm{Ca}_{2}$ $(\mathrm{Mg}, \mathrm{Fe}, \mathrm{Al})_{5}(\mathrm{Al}, \mathrm{Si})_{8} \mathrm{O}_{22}(\mathrm{OH})_{2}$; The amphibole in faux amphibolite has a major cummingtonite $\mathrm{Fe}_{2} \mathrm{Mg}_{5} \mathrm{Si}_{8} \mathrm{O}_{22}(\mathrm{OH})_{2}$ component. The process by which it formed is poorly understood.

Gabbro: A course-grained igneous rock formed by slow cooling of a molten rock (magma) with the composition of basalt. This rock usually forms the lower part of the oceanic crust (Fig. 1).

Goldilocks situation: From the children's story where Goldilocks found Papa Bear's oatmeal too hot, Mama Bear's too cold, and Baby Bear's just right. We find many such situations on the Earth that favor habitability in general and the origin of our own species, both locally and globally. For example, Venus is too hot and Mars is too cold. The ubiquity of Goldilocks situations on our planet is to a major extent the result of sampling bias: we have to survive to observe so we can expect no events like recent extirpation of terrestrial life that would preclude our existence. Philosophers refer to this concept as the weak antropic principle.

Isochron: A line obtained from a graph of isotopic concentration ratios from a suite of rock or mineral samples. Each point is the ratio daughter isotope from radioactive decay divided by stable isotope of same element versus the radioactive parent isotope divided by same stable isotope. These points fall on a line (the isochron) within analytical error if the samples formed at the same time from starting material that had the same initial ratio of daughter to stable isotope but variable parent to daughter ratios. The method requires that the samples behaved thereafter as closed systems. It often works in practice because the time for an initially homogeneous magma to differentiate and crystallize into samples of different parent/ daughter isotopic ratios (days to thousand of years) is much less than the half-lifes (billions of years) of parent isotopes in standard use. The differentiation and crystallization times are frequently much less than the geological times of interest, many millions of years.

Isua: A region in southwestern Greenland that has well studied exposures of old Archaean rocks.

Kimberlite (loose usage): A $\mathrm{MgO}$, water, and $\mathrm{CO}_{2}$-rich magma formed melting of $\mathrm{CO}_{2}$-rich rocks at $\sim 200 \mathrm{~km}$ depth in the Earth's mantle. Some of these rocks are commercial sources of diamond. The magma ascends violently from depth to the surface in hours to days.

Komatiite: A black volcanic rock that is significantly more $\mathrm{MgO}$-rich than basalt. It formed in the past when the mantle was hotter by a high $>25 \%$ fraction of partial melting. A continuum exists between basalt and komatiite. In addition komatiite may partly crystallize at shallow depths leaving basalt. See Arndt (2003) for more on the chemistry and physics of these processes.

Lithosphere: The cool upper part of the Earth, composed of crust and mantle, that moves in 
N.H. Sleep

rigid plates. The base of ocean lithosphere is a thermal boundary that deepens to $\sim 100 \mathrm{~km}$ for old oceanic crust as it spreads away from the ridge axis. The base of continental lithosphere may be either compositional or thermal. Continental lithosphere within stable regions is typically $\sim 200 \mathrm{~km}$ thick.

Mantle: The part of the Earth beneath the crust and above the core (2900 km deep). The depth to the top of the mantle (the Moho) is $\sim 6 \mathrm{~km}$ beneath ocean basins and $\sim 40 \mathrm{~km}$ beneath continents. The mantle is made of an igneous rock called peridotite with olivine $\left(\mathrm{Mg}_{2} \mathrm{SiO}_{4}-\mathrm{Fe}_{2}\right.$ $\left.\mathrm{SiO}_{4}\right)$ as its major mineral at low pressures above $\sim 400 \mathrm{~km}$ depth. This rock also contains silicates of calcium, aluminum, and some sodium. It forms basaltic magma with a moderate fraction of melting and komatiite with a large fraction.

Mush: A partially molten rock with a small (less than few percent) fraction of partial melt. The rock flows slowly over geological time but behaves as solid on the time scale of seismic waves, seconds. Mush of basaltic composition forms gabbro when it freezes at ridge axes (Fig. 1).

Oxic and suboxic (adjectives): Oxic refers to atmosphere or water in equilibrium with atmosphere with significant $\mathrm{O}_{2}$. Crudely, enough free oxygen to support many species of animals. Suboxic refers to lower concentrations of $\mathrm{O}_{2}$, air with tenths of percent $\mathrm{O}_{2}$ and water in equilibrium with it. It supports oxygen-based heterothrophy but not most animals.

Pyroclastic (advective): Refers to the violent eruption of a gas-rich magma as with Pompeii and
Mount St. Helens and the deposits of rock fragments formed when the material comes to rest.

Serpentinite: A rock composed mainly of the mineral serpentine, idealized formula $(\mathrm{Mg}, \mathrm{Fe})_{6}$ $\mathrm{Si}_{4} \mathrm{O}_{10}(\mathrm{OH})_{8}$ and some brucite $(\mathrm{Mg}, \mathrm{Fe})(\mathrm{OH})_{2}$. The rock forms from the reaction of peridotite and water at temperatures below $350^{\circ} \mathrm{C}$. The ferrous iron in the rock reacts with water to form hydrogen gas and magnetite $\mathrm{Fe}_{3} \mathrm{O}_{4}$. The hydrogen with $\mathrm{CO}_{2}$ provides a substrate for modern methanogens at serpentine-fed vents. Serpentine also forms by reaction of water with olivine in basalt and komatiite.

Shale: A rock formed form mud deposited on the seafloor (or sometimes lake or river floor). It is fine grained and rich in clays. Reduced organic carbon accumulates in black shales when it burial is rapid. Shales have very low permeability to water circulation so that carbon once buried is not readily oxidized.

Subduction: The process that returns oceanic lithosphere into the deep mantle. Geologists call the returning lithosphere the slab. The top of the slab (upper oceanic crust and sediments) becomes hotter with increasing depth. At $\sim 100 \mathrm{~km}$ depth, the silicates in the uppermost slab dehydrate, producing a hydrous fluid that ascends into the overlying hot mantle. The hydrous fluid mixes with the hot mantle, which partially melts to form hydrous basalt. The basalt ascends toward the surface feeding volcanoes in island arcs. Fujijama, the Aleutians, and Mount St. Helens are examples. Most of the water in the slab returns to the surface in this way, but most of the carbonate in the slab continues to depth. 


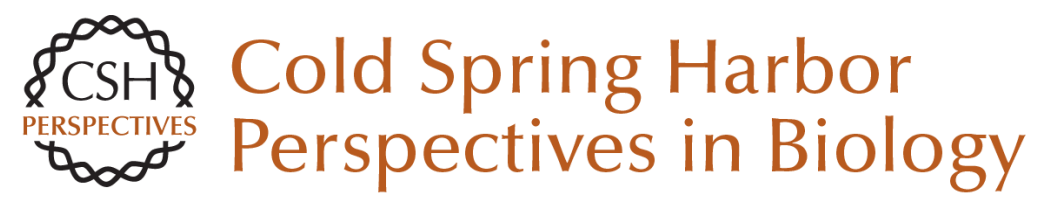

\section{The Hadean-Archaean Environment}

Norman H. Sleep

Cold Spring Harb Perspect Biol 2010; doi: 10.1101/cshperspect.a002527 originally published online May 5,2010

\section{Subject Collection The Origins of Life}

Constructing Partial Models of Cells

Norikazu Ichihashi, Tomoaki Matsuura, Hiroshi Kita, et al.

Ribonucleotides John D. Sutherland

Deep Phylogeny--How a Tree Can Help

Characterize Early Life on Earth

Eric A. Gaucher, James T. Kratzer and Ryan N. Randall

Cosmic Carbon Chemistry: From the Interstellar Medium to the Early Earth Pascale Ehrenfreund and Jan Cami

Origin and Evolution of the Ribosome George E. Fox

Planetary Organic Chemistry and the Origins of Biomolecules Steven A. Benner, Hyo-Joong Kim, Myung-Jung Kim, et al.

Mineral Surfaces, Geochemical Complexities, and the Origins of Life

Robert M. Hazen and Dimitri A. Sverjensky

Historical Development of Origins Research Antonio Lazcano
The Hadean-Archaean Environment

Norman H. Sleep

An Origin of Life on Mars

Christopher P. McKay

Primitive Genetic Polymers

Aaron E. Engelhart and Nicholas V. Hud

Membrane Transport in Primitive Cells Sheref S. Mansy

The Origins of Cellular Life Jason P. Schrum, Ting F. Zhu and Jack W. Szostak

From Self-Assembled Vesicles to Protocells Irene A. Chen and Peter Walde

The Origin of Biological Homochirality Donna G. Blackmond

Earth's Earliest Atmospheres Kevin Zahnle, Laura Schaefer and Bruce Fegley

For additional articles in this collection, see http://cshperspectives.cshlp.org/cgi/collection/

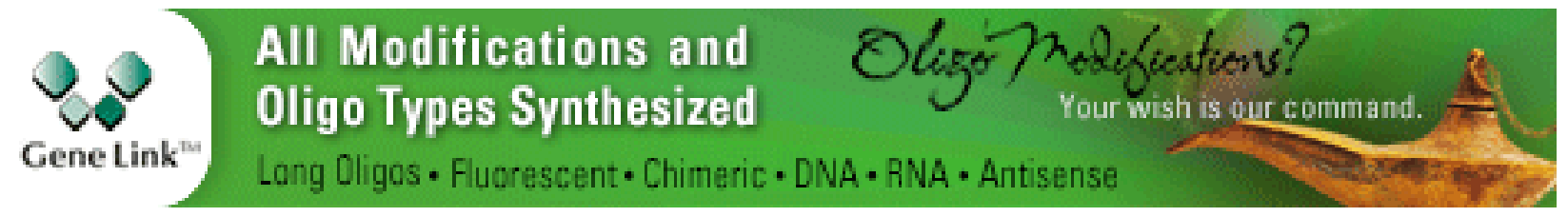

Copyright @ 2010 Cold Spring Harbor Laboratory Press; all rights reserved 